\title{
Analysis of Blood Glucose and Plasma Insulin Levels of Tea and Cinnamon Tea Drink against People with Diabetes Mellitus Type 2
}

\author{
Liana Verdini ${ }^{1, *}$, Fransiska Rungkat Zakaria ${ }^{2}$, and Endang Prangdimurti ${ }^{2}$ \\ ${ }^{I}$ Postgraduate Program, Bogor Agricultural University, Bogor - 16680, West Java, Indonesia \\ ${ }^{2)}$ Department of Food Science, Faculty of Agricultural Technology, Bogor Agricultural University, Bogor, - \\ 16680, West Java, Indonesia
}

\begin{abstract}
Diabetes Mellitus is a chronic disease characterized by increased blood glucose levels as a result of a lack of insulin or the body is unable to use insulin. One of the plants that have the potential to lower blood glucose levels of diabetics mellitus is cinnamon and tea. Testing the effect of cinnamon tea and tea to the insulin that play a role in decreasing blood glucose levels. Therefore, to investigate the effect of cinnamon tea and tea drinks is the most effective on blood glucose levels, body weight, and plasma insulin levels respondents diabetes mellitus type 2. Treatments consisted of a control group and two treatment groups. The control group is a negative control (diabetes mellitus without any treatment). The treatment group consisted of treatment of tea and cinnamon tea. Respondents who have diabetes mellitus type 2 measured levels of blood glucose, plasma insulin levels against all test groups. Analysis of blood glucose using a glucometer showed changes in the results for each respondent is different treatment; treatment of cinnamon drink had a decrease in the blood glucose level is different from the tea drink treatment experienced a significant rise in blood glucose. Analysis of insulin using ELISA showed changes in work procedures different results; treatment cinnamon increased insulin levels while the tea treatment decreased insulin levels. This study shows that the influence of cinnamon drink to the reduction of blood glucose and insulin levels occurred in respondents with diabetes mellitus type 2.
\end{abstract}

Keywords: Diabetes mellitus; cinnamon extract; blood glucose; plasma insulin

\section{Introduction}

Diabetes mellitus (DM) is a chronic disease due to errors of metabolism in which the sufferer continues to increase every year. According to the International Diabetes Federation (IDF) diabetes mellitus world reached, 382 million people were $80 \%$ live in developing countries, and 85 to $95 \%$ entered into a diabetes type 2 Indonesia itself ranked seventh state with the highest number of diabetics around 8,5 million people.

One of the causes of diabetes, especially diabetes mellitus type 2 is a state of oxidative stress can induce insulin resistance in peripheral tissues and impair insulin secretion from pancreatic beta cells. Furthermore, the conditions of hyperglycemia is also involved in the formation of free radicals autooxidation [1]. Hyperglycemia causes glucose, protein glycation, and activation of the metabolic pathway of polyol, which further accelerates the formation of reactive oxygen compounds. In order to curb oxidative damage is needed antioxidants. Increased supply enough antioxidants affect the formation of oxidative stress in patients with diabetes type 2 despite the application of antioxidants on diabetic patients is still quite controversial [2].

Cinnamon and green tea, including herbal treatment of diabetes [3,4]. Cinnamon has prosianidin compounds that can act like insulin for increasing the glucose uptake [5]. Cinnamon also has the ability antihyperglycemic and potentially reduced post-prandial glucose and fasting [6]. Cinnamon polyphenols also increase the activity of SOD (Super Oxide Dismutase). Cinnamon water-soluble compounds that cinnulin succeeded in lowering fasting blood glucose levels of $8.4 \%$ in patients with pre diabetes [7, 8]. Cinnulin also effectively lowers fasting blood glucose levels in mice who are obese due to a high fat diet [9].

Tea as a beverage consumed both had the highest content of antioxidants (polyphenols) are high. Tea polyphenol content reaches $30-40 \%$ dry weight of tea [10]. Compounds tea catechins are epigallocatechin gallate (EGCG) can improve insulin uptake and influence the process of gluconeogenesis [9, 11, 12]. Both above foods are better utilized as a food or supplement. The result of both the diabetes is still a lot of difference. This study aimed to study the effect of cinnamon and tea beverages to patients with diabetes mellitus type 2 in Indonesia. 


\subsection{Preparations product}

\section{Materials And Methods}

Materials used during the intervention respondents diabetes mellitus type 2 is tea and cinnamon tea drink from PT. Nutrifood Indonesia with the composition of the main ingredients is green tea extracts, black tea extracts, cinnamon extracted obtained in March 2014.

\subsection{Subject}

Based on calculations using formula's different test, obtained and samples of nine people. Anticipation dropout $10 \%$, the number of respondents required is 10 people. There are two treatment groups, the total number of respondents is at least 20 people. The study obtained the permission of conduct (ethical clearance) of the Ethics Committee Institute for Research and Community Service Atma Jaya Catholic University in Jakarta with the number 615/II/LPPM-PM.10.05/07/2014.

\subsection{Analysis of Blood Glucose}

The analysis is the analysis of glucose made weekly fasting blood glucose and post-prandial glucose. Analysis of the weekly blood glucose was measured on days $0,6,12,18,24,30$ and 35 days. Each blood glucose measurement respondent was asked to fast for at least eight hours.

\subsection{Analysis of Plasma Insulin Levels}

A total of $100 \mathrm{~mL}$ of plasma which had been diluted with carbonate/bicarbonate buffers incorporated into the 96 well microplate was then incubated at $4{ }^{\circ} \mathrm{C}$ overnight. The liquid in the microplate then removed and washed with PBST solution of $250 \mathrm{~mL} /$ well. The washing liquid is left in a minute and then discarded wash solution. Washing is done three times. Skim milk was added $100 \mathrm{~mL}$ of $5 \%$ in each well and incubated at $37^{\circ} \mathrm{C}$ for 1 hour. The liquid in the microplate then removed and washed with PBST 3 times. Primary antibody was added into each well that is a monoclonal antibody anti human insulin produced in mice as much as $100 \mathrm{~mL}$ and incubated at $37^{\circ} \mathrm{C}$ for 1 hour. The liquid in the microplate then removed and washed with PBST 3 times. HRP polyclonal antibody anti-mouse $\mathrm{IgG}$ and then added as much as $100 \mathrm{~mL}$ and incubated at $37^{\circ} \mathrm{C}$ for 1 hour. The liquid in the microplate then removed and washed with PBST 3 times. $50 \mathrm{~mL}$ of TMB substrate was added and incubated in the dark room. The incubation time begins after the addition of each solution at the last well. The intensity of the color formed is read by a microplate readers at a wavelength of $450 \mathrm{~nm}$.

\subsection{Data Analysis}

Data were analyzed using SPSS software version 22 . The preliminary data homogeneity test is done by using analysis of variance (ANOVA). Respondent data normality test was conducted by Shapiro Wilk. The effects of treatment on the health of the respondents were analyzed using paired $t$ test if the data are normally distributed or by using the Wilcoxon test if the data is not normally distributed. Effects of treatment of the changes that occurred in each treatment group were analyzed using One-Way ANOVA with Duncan advanced test if the data is normal or the Kruskal-Wallis test if the data is not normally distributed.

\section{Results and discussion \\ 3.1 Blood Glucose}

Fasting glucose respondents cinnamon and tea was measured before and after the intervention activities and also every week during the intervention takes place. Fasting glucose measurements done in the morning between 07.00 until 09.00. Fasting glucose analysis results before and after the intervention can be seen in Table 1. Fasting glucose patients with diabetes mellitus type 2 who eat cinnamon decreased by $244.58 \mathrm{mg} / \mathrm{dL}$ while the consumption of tea had increased fasting glucose of $238.50 \mathrm{mg} / \mathrm{dL}$. This illustrates the provision of woody sweet drinks can lower fasting glucose respondents. Further analysis results showed two treatments made no difference significantly decrease fasting glucose. Giving cinnamon for diabetes mellitus in the form of extract or powder to a fasting blood glucose of respondents did give different results but generally give effect to decrease as shown in Table 2.

Table 1 Comparison of fasting blood glucose respondents before and after of each treatment group

\begin{tabular}{|c|c|c|c|c|}
\hline \multirow{2}{*}{ No. } & \multicolumn{2}{|c|}{ Cinnamon $(\mathrm{n}=12)$} & \multicolumn{2}{c|}{ Tea $(\mathrm{n}=10)$} \\
\cline { 2 - 5 } & $\begin{array}{c}\text { Before } \\
(\mathrm{mg} / \mathrm{dL})\end{array}$ & After $(\mathrm{mg} / \mathrm{dL})$ & $\begin{array}{c}\text { Before } \\
(\mathrm{mg} / \mathrm{dL})\end{array}$ & $\begin{array}{c}\text { After } \\
(\mathrm{mg} / \mathrm{dL})\end{array}$ \\
\hline 1 & 154 & 197 & 183 & 199 \\
\hline 2 & 393 & 399 & 177 & 491 \\
\hline 3 & 188 & 114 & 116 & 115 \\
\hline 4 & 245 & 322 & 191 & 172 \\
\hline 5 & 174 & 115 & 204 & 296 \\
\hline
\end{tabular}




\begin{tabular}{|r|c|c|c|c|}
\hline 6 & 207 & 164 & 135 & 167 \\
\hline 7 & 178 & 106 & 298 & 392 \\
\hline 8 & 407 & 348 & 156 & 162 \\
\hline 9 & 310 & 318 & 180 & 161 \\
\hline 10 & 572 & 457 & 203 & 230 \\
\hline 11 & 224 & 243 & & \\
\hline 12 & 126 & 152 & & \\
\hline Average & 264.83 & 244.58 & 184.30 & 238.50 \\
\hline
\end{tabular}

Analysis of the weekly fasting glucose as seen in Table 3 showed no difference in fasting glucose between treatment of tea and cinnamon for measurements up to day 35. Although not significant, the respondents were using cinnamon showed weekly fasting glucose conditions is always lower than before the intervention while respondents tea just the opposite. The decrease in fasting glucose occurred in day 18 is $18.54 \%$. Kruskal-Wallis test results showed that the measurements were not significantly different to changes in fasting glucose respondents.

Table 2. Comparison of fasting blood glucose respondents with related research

\begin{tabular}{|c|c|c|c|c|c|c|c|c|c|c|}
\hline \multirow[t]{2}{*}{ Researcher } & \multirow{2}{*}{$\begin{array}{l}\text { Respondent } \\
\text { Type }\end{array}$} & \multirow[t]{2}{*}{ Country } & \multirow[t]{2}{*}{ Year } & \multirow[t]{2}{*}{ Doses } & \multirow{2}{*}{$\begin{array}{l}\text { Cinnamon } \\
\text { Shapes }\end{array}$} & \multirow{2}{*}{$\begin{array}{l}\text { Duration } \\
\text { (week) }\end{array}$} & \multicolumn{4}{|c|}{ Blood Glucose (mmol/L) } \\
\hline & & & & & & & $\mathrm{n}$ & $\begin{array}{l}\text { Pra / } \\
\text { Pasca }\end{array}$ & $\mathrm{n}$ & $\begin{array}{l}\text { Pra / } \\
\text { Pasca }\end{array}$ \\
\hline \multirow[t]{2}{*}{ Mang ${\mathrm{et} a l^{7}}^{7}$} & DMT2 & Germany & 2006 & $6 \mathrm{~g}$ & Extract & 16 & 32 & $8,7 \pm 1,9$ & 33 & $9,3 \pm 2,3$ \\
\hline & & & & & & & & $8,3 \pm 1,6$ & & $8,2 \pm 1,7^{*}$ \\
\hline \multirow[t]{2}{*}{$\begin{array}{l}\text { Ziegenfuss et } \\
a l^{16}\end{array}$} & \multirow[t]{2}{*}{$\begin{array}{l}\text { Metabolic } \\
\text { syndrome }\end{array}$} & American & 2006 & $\begin{array}{l}500 \\
\mathrm{mg}\end{array}$ & Extract & 12 & 10 & $6,2 \pm 0,6$ & 12 & $6,4 \pm 0,7$ \\
\hline & & & & & & & & $6,3 \pm 0,8$ & & $5,9 \pm 1,1^{*}$ \\
\hline \multirow[t]{2}{*}{ Roussel et al ${ }^{13}$} & \multirow[t]{2}{*}{$\begin{array}{l}\text { Pre } \\
\text { diabetic }\end{array}$} & American & 2009 & $\begin{array}{l}500 \\
\mathrm{mg}\end{array}$ & Extract & 12 & 11 & $6,2 \pm 0,2$ & 11 & $5,7 \pm 0,2$ \\
\hline & & & & & & & & $6,3 \pm 0,3$ & & $6,3 \pm 0,1$ \\
\hline \multirow[t]{2}{*}{ Li et $a l^{6}$} & DMT2 & China & 2013 & $\begin{array}{l}120 \\
\mathrm{mg}\end{array}$ & Extract & 13 & 20 & $8,9 \pm 1,2$ & 23 & $9,0 \pm 1,2$ \\
\hline & & & & & & & & $8,7 \pm 2,0$ & & $8,0 \pm 1,1^{*}$ \\
\hline \multirow[t]{2}{*}{ This research*) } & DMT2 & Indonesian & 2015 & $\begin{array}{l}510 \\
\mathrm{mg}\end{array}$ & Extract & 5 & 12 & $9,6 \pm 3,0$ & 12 & $14,7 \pm 7,3$ \\
\hline & & & & & & & & $12,1 \pm 6,6$ & & $13,6 \pm 6,7$ \\
\hline
\end{tabular}

*)Data is presented as the form of average value $\pm \mathrm{SD}$

Table 3 Results of the weekly fasting glucose treatment

\begin{tabular}{|l|l|l|}
\hline \multirow{2}{*}{ Day to- } & \multicolumn{2}{|c|}{ Treatment } \\
\cline { 2 - 3 } & \multicolumn{1}{|c|}{ Cinnamon $(\mathrm{n}=5)$} & \multicolumn{1}{c|}{ Tea $(\mathrm{n}=5)$} \\
\hline 0 & $219,00 \pm 103,27^{\mathrm{a}}$ & $178,20 \pm 36,45^{\mathrm{a}}$ \\
\hline 6 & $200,00 \pm 138,96^{\mathrm{a}}$ & $220,80 \pm 64,80^{\mathrm{a}}$ \\
\hline 12 & $200,60 \pm 113,05^{\mathrm{a}}$ & $217,40 \pm 82,40^{\mathrm{a}}$ \\
\hline 18 & $178,40 \pm 103,85^{\mathrm{a}}$ & $239,80 \pm 146,16^{\mathrm{a}}$ \\
\hline 24 & $197,20 \pm 116,06^{\mathrm{a}}$ & $262,20 \pm 182,40^{\mathrm{a}}$ \\
\hline 30 & $183,60 \pm 90,35^{\mathrm{a}}$ & $247,80 \pm 200,05^{\mathrm{a}}$ \\
\hline 35 & $203,00 \pm 122,24^{\mathrm{a}}$ & $260,80 \pm 145,19^{\mathrm{a}}$ \\
\hline
\end{tabular}

*)Data is presented as the form of average value $\pm \mathrm{SD}$

**)The same letters are not significantly different signaling

\subsection{Plasma Insulin Levels}

Insulin is a hormone secreted by the pancreatic beta cells that function to maintain normal blood glucose levels by facilitating the uptake of glucose, regulate the metabolism of carbohydrates, fats, and proteins, and help cell division and growth $[13,14]$. Generally, insulin levels will increase along with the increase of glucose in plasma. In patients with diabetes mellitus type 2, the amount of insulin available is not proportional to the amount of glucose in plasma insulin response to glucose causes will fall by the increasingly high number of plasma glucose [15]. Extract the cinnamon especially polyphenol increase the autophosphorylation of the insulin receptor, is also increasing the number of insulin receptors (IR)- $\beta$, IR substrate-1 (IRS1) and GLUT4 that increase glucose uptake into the cell [16]. 
Analysis of Blood Glucose and Plasma Insulin Levels of Tea and Cinnamon Tea Drink Against ..

Table 4 Comparison of insulin level before and after of each treatment group

\begin{tabular}{|c|c|c|c|c|}
\hline \multirow{2}{*}{ No } & \multicolumn{2}{|c|}{ Cinnamon $(\mathrm{n}=12)$} & \multicolumn{2}{c|}{ Tea $(\mathrm{n}=10)$} \\
\cline { 2 - 5 } & Before & After & Before & After \\
\hline 1 & 0.239 & 0.277 & 0.318 & 0.194 \\
\hline 2 & 0.188 & 0.300 & 0.249 & 0.172 \\
\hline 3 & 0.237 & 0.314 & 0.333 & 0.170 \\
\hline 4 & 0.208 & 0.404 & 0.269 & 0.237 \\
\hline 5 & 0.296 & 0.397 & 0.312 & 0.166 \\
\hline 6 & 0.229 & 0.303 & 0.305 & 0.154 \\
\hline 7 & 0.424 & 0.344 & 1.422 & 0.673 \\
\hline 8 & 0.198 & 0.325 & 0.304 & 0.189 \\
\hline 9 & 0.182 & 0.311 & 0.406 & 0.234 \\
\hline 10 & 0.258 & 0.318 & 0.285 & 0.138 \\
\hline 11 & 0.269 & 0.237 & & \\
\hline 12 & 0.283 & 0.329 & & 0.226 \\
\hline Average & 0.251 & 0.322 & & 0.411 \\
\end{tabular}

The results of the analysis of plasma insulin levels by semi-quantitative patients with type 2 diabetes mellitus treated with cinnamon showed a significant increase of 3,22\%. While respondents with tea treatment actually decreased plasma insulin levels by $2,26 \%$ as shown in Table 4 . The presence of elevated levels of insulin and a decrease in fasting blood glucose levels of diabetics are using cinnamon for five weeks showed that cinnamon is effective in diet therapy patients with diabetes mellitus type 2 . Results of analysis of variance to the two treatments showed that cinnamon provides increased levels of insulin were significantly different from the treatment of tea.

Compared with the findings with other studies, in a sample of extract of cinnamon 6 grams in Germany with a range of testing 16 weeks seen decreased blood glucose levels, in samples of cinnamon extract at $500 \mathrm{mg}$ in the US tumbled in blood glucose levels at the time of testing for 12 weeks while the relatively short time is five weeks cinnamon extracted samples of $510 \mathrm{mg}$ in Indonesia decreased blood glucose levels. By this, it can be stated that the consumption of cinnamon in a relatively quick time with a dose that has been widely used can lower blood glucose levels of patients with diabetes mellitus type 2 .

\section{Conclusion}

Based on the results of this study by consuming two packs of beverages containing respectively 255 mg cinnulin can improve the health of patients with diabetes mellitus type 2 . It is evident to the decline in value of their fasting blood glucose and insulin levels increase in patients with diabetes mellitus type 2 who ate the drinks for five weeks. Therefore, cinnamon can be used as one of the drinks in implementing diet diabetes mellitus type 2.

\section{Acknowledgement}

The author would like to thank Scholarship Graduate of the Interior of the Directorate General of Higher Education, Ministry of Research, Technology and Higher Education, PT. Nutrifood Indonesia as founders and material's research as well as the Bogor Agricultural Institute for the facility to conduct this study and research.

\section{References}

[1]. Oberley, LW. 1988. Free radicals and diabetes. Free Radical Biol. Med. 5: 113-24

[2]. Zatalia SR dan Sanusi H. 2013. The role of antioxidants in the pathophysiology, complications, and management of diabetes melitus. Acta Medica Indonesian 45 (2) : $141-147$.

[3]. Li R, Liang T, Xu L, Li Y, Zhang S, Duan X. 2013. Protective effect of cinnamon polyphenols against STZ-diabetic mice fed high sugar, high fat diet and its underlying mechanism. J. Food and Chemical Toxicology $51: 419-425$.

[4]. Mang B, Wolters M, Schmitt B, Kelb K, Lichtinghagen R, Stichtenoth DO, et al. 2006. Effects of a cinnamon extract on plasma glucose, $\mathrm{HbA}_{1 \mathrm{C}}$, and serum lipids in diabetes melitus type 2. European Journal of Clinical Investigation (36) : 340-344.

[5]. Anderson RA, Broadhurst CL, Polansky MM et al. 2004. Isolation and characterization of polyphenol type-A polymers from cinnamon with insulin-like biological activity. J Agric. Food Chem. (52) : 65-70.

[6]. Kirkham S, Akilen R, Sharma S, and Tsiami A. 2012. The potential of cinnamon to reduce blood glucose levels in patienets with type 2 diabetes and insulin resistance. J. Diabetes, Obesity and Metabolism (11) : 1100-1113.

[7]. Ziegenfuss TN, Hofheins JE, Mendel RW, Landis J, and Anderson RA. 2006. Effect of water soluble cinnamon extract on body composition and features of the metabolic syndrome in prediabetic men and women. J. Intl. Society of Sports Nutrition 3(2) : 4553.

[8]. Cheng DM, Kuhn P, Poulev A, Rojo LE, Lila MA, dan Raskin L. 2012. In vivo and in vitro antidiabetic effects of aqueous cinnamon extract and cinnamon polyphenol-enhanced food matrix. J. Food Chemistry $135: 2994$ - 3002.

[9]. Grant P and Dworakowska D. 2013. Tea and diabetes: the laboratory and the real world in Tea in Health and Disease Prevention. Elsevier Inc: 661-674.

[10]. Park JH, Bae JH, Im SS, and Song DK. 2014. Green tea and type 2 diabetes : A review. J. Integrative Medicine Research (3) : 4-10.

[11]. Wilcox G. 2005. Insulin and insulin resistance : Review article. J. Clin Biochem Rev 26:19-39.

[12]. DeFronzo RA. 2004. Pathogenesis of type 2 diabetes melitus. J. Med Clin N Am $88: 787-835$. 
Analysis of Blood Glucose and Plasma Insulin Levels of Tea and Cinnamon Tea Drink Against ..

[13]. Rafehi H, Ververis K, dan Karagiannis TC. 2012. Controversies surrounding the clinical potential of cinnamon for the management of diabetes : Review article. Diabetes, Obesity and Metabolism $14: 493-499$.

[14]. Mohamed S. 2014. Functional foods against metabolic syndrome (obesity, diabetes, hypertension and dyslipidemia) and cardiovascular disease. J. Trends in Food Science and Technology (35) : 114-128.

[15]. Najm W and Lie D. 2010. Herbal use for diabetes, obesity, and metablic syndrome. J. Prim Care Clin Office Pract (37) : $237-254$.

[16]. Roussel AM, Hininger I, Benaraba R, Ziegenfuss TN, Anderson RA. 2009. Antioxidant effects of cinnamon extract in people with impaired fasting glucose that are overweight or obese. J. Am Cloo Nutr $28: 16-21$. 